\title{
Detection of Mycobacterium avium subspecies in the gut associated lymphoid tissue of slaughtered rabbits
}

\author{
Rakel Arrazuria ${ }^{1}$, Iker A Sevilla', Elena Molina ${ }^{1}$, Valentín Pérez², Joseba M Garrido ${ }^{1}$, Ramón A Juste \\ and Natalia Elguezabal ${ }^{1 *}$
}

\begin{abstract}
Background: Rabbits are susceptible to infection by different species of the genus Mycobacterium. Particularly, development of specific lesions and isolation of Mycobacterium avium subsp. avium and Mycobacterium avium subsp. paratuberculosis, both subspecies of the M. avium complex, has been reported in wildlife conditions. Although, rabbit meat production worldwide is 200 million tons per year, microbiological data on this source of meat is lacking and more specifically reports of mycobacterial presence in industrially reared rabbit for human consumption have not been published. To this end, we sought mycobacteria by microbiological and histopathological methods paying special attention to Mycobacterium avium subsp. paratuberculosis in rabbits from commercial rabbitries from the North East of Spain.
\end{abstract}

Results: M. avium subsp. paratuberculosis was not detected either by culture or PCR. However, Mycobacterium avium subsp. avium was detected in $15.15 \%$ (10/66) and Mycobacterium avium subsp. hominissuis was detected in $1.51 \%(1 / 66)$ of gut associated lymphoid tissue of sampled animals by PCR, whereas caecal contents were negative. $9 \%(6 / 66)$ of the animals presented gross lesions suggestive of lymphoid activation, $6 \%(4 / 66)$ presented granulomatous lesions and $3 \%(2 / 66)$ contained acid fast bacilli. Mycobacterial isolation from samples was not achieved, although colonies of Thermoactinomycetes sp. were identified by $16 \mathrm{~s}$ rRNA sequencing in $6 \%(4 / 66)$ of sampled animals.

Conclusions: Apparently healthy farmed rabbits that go to slaughter may carry M. avium subspecies in gut associated lymphoid tissue.

Keywords: Animal pathogens, Epidemiology, Mycobacterium avium subsp, Mycobacterium avium complex, Thermoactinomyces sp, Rabbits, Slaughter

\section{Background}

Rabbits have been found to be naturally susceptible to Mycobacterium avium subsp. paratuberculosis (Map) infection in the wild [1-4], to Mycobacterium avium subspecies infection in natural conditions, specifically Mycobacterium avium subsp. avium (Maa) in pigmy rabbits [5] and moderately susceptible to Map in laboratory conditions $[6,7]$.

\footnotetext{
* Correspondence: nelguezabal@neiker.eus

'Animal Health Department, NEIKER-Instituto Vasco de Investigación y

Desarrollo Agrario, Berreaga, 1, 48160 Derio, Bizkaia, Spain

Full list of author information is available at the end of the article
}

Map and Maa are subspecies of Mycobacterium avium, as well as Mycobacterium avium subsp. silvaticum (Mas) and Mycobacterium avium subsp. hominissuis (Mah) [8]. From an epidemiologic point of view, Maa is typically virulent for birds and small terrestrial mammals causing a range of lesions that go from characteristic tuberculous lesions in parenchymatous organs, to lymphadenitis and disseminated infection [9-11]. Mah has the human [12] and the pig [13] as its primary hosts and it is frequently found in soil [14]. Map is the causal agent of paratuberculosis in ruminants and it has been controversially associated with human inflammatory bowel disease, more precisely with Crohn's disease [15-17] and also diabetes 
mellitus [18]. Its prevalence in slaughtered cattle in Europe has been estimated to be up to $50 \%$ [19]. Mas has been isolated from wood pigeons [20], roe deer [21] and horses causing tuberculous-like lesions in these animals [22]. However, since there is a controversy about the real existence of Mas as a unique subspecies independent of Maa [23], for the present work we will consider Mas as part of Maa, and jointly refer to them as Maa/Mas.

Mycobacterium avium subspecies members are widely spread in the environment and often enter in contact with animals and humans. Transmission from animals to humans can occur either through the consumption of contaminated foods or via direct contact with an infected animal. Apparently healthy animals thereby may represent a reservoir for Mycobacterium avium subspecies and these pathogens may enter the food chain during slaughter. Most work focused on the detection of $M$. avium subspecies in animal species for human consumption has been performed on meat products. Map has been detected in beef, pork and chicken [24], whereas Mah has been detected in beef, pork and lamb [24]. Detection of non-tuberculous mycobacteria or Mycobacterium avium subspecies at slaughter has been described in lymph nodes of pigs [25-27] and detection of Map has been reported in lymph nodes, muscle and faeces of both dairy and beef cattle [28].

Mycobacterium avium subspecies presence in rabbits in wild conditions led us to hypothesize that these mycobacteria could also be present in commercial rabbits that go to slaughter and thus represent a route of exposure for humans. The aim of the present study was to carry out a small survey on the frequency of mycobacterial microorganisms detected by solid and liquid culture and by a tetraplex real-time PCR for Mycobacterium genus, $M$. avium subspecies and $M$. tuberculosis complex in gut associated lymphoid tissue (GALT) and caecal contents of apparently healthy rabbits at slaughter.

\section{Methods}

\section{Ethics statement}

Animals used in this study did not undergo any manipulation prior to stunning for standard industrial slaughter according to the pertinent legislation. For this reason, no specific ethical approval was required.

\section{Animals and sampling}

We contacted the official veterinarian of the nearest rabbit slaughterhouse to set-up a sampling schedule. This study was based on samplings that took place from May to October of 2013 (decontamination procedure set-up and PCR evaluation) and during January and February of 2014 (proper study) in a rabbit slaughterhouse (Basque Country, Spain) processing 1300000-
1400000 rabbits annually. Rabbits are typically slaughtered with an average age of two months and average live weight around 1.8-2.2 kg (http://www.magrama.gob.es/ es/ganaderia/temas/produccion-y-mercadosganaderos/ INDICADORES_ECONÓMICOS_SECTOR_CUNÍCOLA_ 2013_tcm7-330314.pdf). Breeding rabbits are slaughtered at about $2-2.5$ years of age. Production rabbits are often outbred in order to maximize meat production [29]. This slaughterhouse was operated by an agriculture cooperative company and complied with the pertinent Basque (Basque Government Decree 454/ 1994), Spanish (Spanish Government Law 32/2007 and Royal decree 731/2007) and European (Council Regulation (EC) No 1099/2009) legislation on animal welfare under the supervision of official veterinarians and the samples obtained were authorized by the slaughterhouse managers.

A total of 12 animals (decontamination procedure set-up and PCR evaluation) and 66 animals (proper rabbit slaughterhouse study) from 21 farms scattered in 6 provinces of North-East Spain were sampled. Samples were drawn from two young animals from each batch of sacrifice and from a third additional breeding animal, if the batch included breeding rabbits. Samples were kept in refrigeration for 6-12h before being processed.

\section{Decontamination procedure}

In order to determine the optimum $\mathrm{NaOH}$ concentration for decontamination initial set-up experiments were performed. Mucosa from sacculus rotundus and vermiform appendix from 12 rabbits were used to test decontamination with $2 \%, 4 \%, 6 \%$ and $8 \% \mathrm{NaOH}$. Decontamination procedures were run for 10 and $15 \mathrm{~min}$. Contamination was observed in both solid and MGIT culture at $\mathrm{NaOH}$ concentrations lower than $6 \%$ for both 10 and $15 \mathrm{~min}$. $6 \% \mathrm{NaOH}$ for 15 min was the lowest concentration that resulted in no contaminated samples. For this reason, the final decontamination procedure was performed with these conditions. Also manufacturer's instructions do not recommend running decontamination for more than 15 min or $\mathrm{NaOH}$ concentrations higher than $6 \%$ (BACTEC $^{\mathrm{mm}}$ MGIT ${ }^{\mathrm{r}} 960$ ).

$10 \mathrm{ml}$ of sterile water were added to $2 \mathrm{~g}$ of sample tissue. Homogenization was then performed on a Stomacher blender for $1 \mathrm{~min}$ at medium speed. Afterwards, the homogenized solution was transferred to a tube and $10 \mathrm{ml}$ of $6 \% \mathrm{NaOH}$ were added. After a vortex mix, the suspension was incubated for $15 \mathrm{~min}$ at room temperature before neutralization with $15 \mathrm{ml}$ of phosphate buffer. The suspension was mixed well and centrifuged for $20 \mathrm{~min}$ at $2,885 \times \mathrm{g}$ and the supernatant was discarded. Pellets were suspended in $2 \mathrm{ml}$ of sterile water. 


\section{Culture}

\section{Solid culture}

Four drops $(150 \mu \mathrm{l}) /$ per tube of the decontaminated suspension were seeded on solid media: Herrold's Egg Yolk Medium (HEYM); Middlebrook 7H10 with penicillin, amphotericin B, and chloramphenicol; Lowenstein-Jensen with penicillin, amphotericin B and supplemented with mycobactin J and Tsukamura minimal media with cycloheximide [30]. All seeded tubes were incubated at $37+/-1{ }^{\circ} \mathrm{C}$ and checked for growth at 8, 12, 16 and 20 weeks. After seeding on solid culture, the remaining inoculum was used for liquid culture.

\section{Liquid culture}

Pellets destined to liquid culture were seeded on BBL Mycobacteria Growth Indicator Tubes (MGIT) supplemented with BACTEC MGIT growth supplement and BBL MGIT PANTA (Becton, Dickinson and Company). Tubes were incubated for 45 days in a BACTEC MGIT 960 System and time to detection (TTD) values were recorded.

\section{PCR evaluation}

PCR performance on spiked mucosa was evaluated since this specimen is known to be tricky because of the presence of PCR inhibitors.

\section{Inocula preparation for tissue spiking}

Mah Strain 104 was grown in Middlebrook 7H9 (M7H9) broth supplemented (v/v) with $10 \%$ Middlebrook OADC enrichment (Becton, Dickinson and Company, MD, USA), $0.2 \%$ glycerol and $0.05 \%$ Tween 80 (Sigma-Aldrich, Co. Ltd., Haverhill, UK). Mycobacteria were harvested by centrifugation at $2,800 \times \mathrm{g}$. Pellets were washed twice in phosphate buffered saline (PBS). Mycobacteria were resuspended in PBS containing $0.2 \%$ glycerol and $0.05 \%$ Tween 80 (PBS-GT). Bacterial suspensions were adjusted to 1 McFarland unit after turbidity measurements were performed with a Densicheck densitometer (Bio-Mérieux, Marcy L'Etoile, France). Five ten-fold dilutions of the bacterial suspensions were prepared in PBS-GT and the highest, medium and lowest, with a 2 log difference between each of them were used to inoculate negative tissues. To verify the viable number of CFU, the inocula were plated onto appropriately supplemented agar-solidified M7H9 flasks.

\section{Mucosa spiking}

Mucosa was scraped from vermiform appendix tissue from 12 apparently healthy rabbits previously confirmed to be negative for the presence of mycobacteria by PCR, culture and histopathology and it was thoroughly mixed and homogenized. The blended tissues were divided in batches of $1 \mathrm{~g}$ of mixture per stomacher bag. The stomacher bags were inoculated with $100 \mu$ l of one of each of the previously adjusted bacterial suspensions (high, medium and low). $300 \mathrm{mg}$ of the homogenate spiked tissues were extracted as described in the DNA extraction section and MycMavMtc PCR [31]. In cases where PCR inhibition took place $1 / 2$ and $1 / 4$ dilutions of the extracted DNA were performed previous to PCR reaction and this showed to be enough to prevent inhibition.

\section{Slaughterhouse sample study}

A total of 66 animals (48 young and 18 breeding animals) were sampled and different steps that are summarized on Fig. 1 were taken to investigate the specimens.

Briefly, sacculus rotundus and vermiform appendix were scraped for mucosa and caecal contents were collected. Part of each sample was used for direct molecular detection and part for decontamination and subsequent culture. Based on set-up results, the final decontamination procedure was performed with $6 \% \mathrm{NaOH}$ as described in the decontamination procedure section because it was the lowest concentration found to inhibit contamination. Both solid and liquid cultures were performed followed by PCR confirmation and sequencing of the 16Sr RNA gene when non-mycobacterial colonies were isolated.

Histopathological analysis was performed on samples of sacculus rotundus and vermiform appendix of a total of 22 rabbits (14 young rabbits and 8 breeding rabbits) including animals with and without macroscopic lesions.

\section{DNA extraction}

\section{Spiked tissues and fresh rabbit slaughterhouse samples}

DNA extraction was performed on spiked mucosa (PCR evaluation), sacculus rotundus, vermiform appendix and caecal content (slaughterhouse study), using

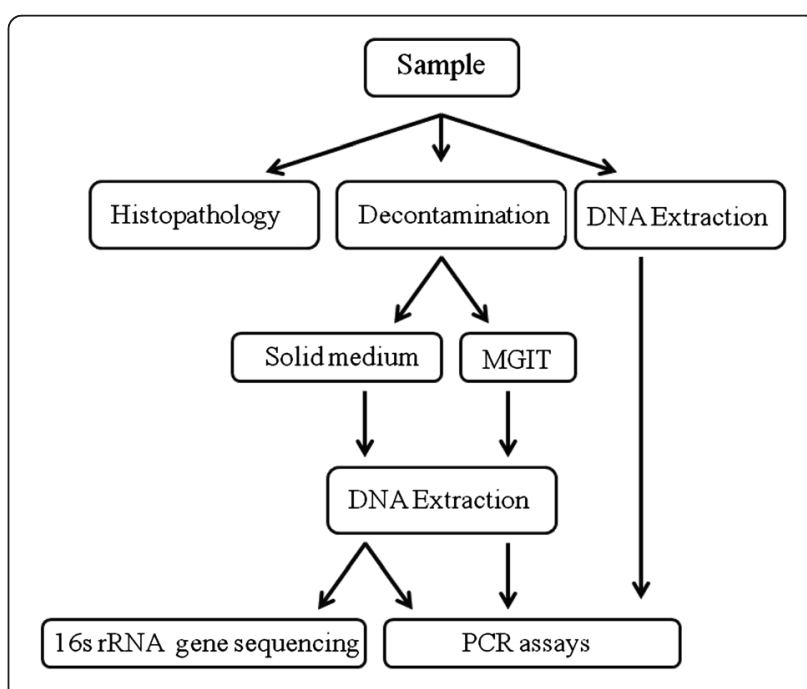

Fig. 1 Experimental scheme showing methods followed at each stage 
DNA Extract-VK (Vacunek S.L, Bizkaia, Spain) following manufacturer's instructions with modifications. Briefly, $300 \mathrm{mg}$ of tissue or caecal content were weighed in a microtube. $250 \mu \mathrm{l}$ of sterile distilled water, plus $250 \mu \mathrm{l}$ of VK-Lysis buffer and $300 \mathrm{mg}$ of VK-extraction beads were added to the tissue and homogenized at $30 \mathrm{~Hz}$ during $10 \mathrm{~min}$ on TissueLyser II (Qiagen). Following homogenization, samples were centrifuged at 7,000 $\times \mathrm{g}$ for $5 \mathrm{~min}$ and $200 \mu \mathrm{l}$ of the supernatant transferred to a new vial. $25 \mu \mathrm{l}$ of Proteinase K were added to the previous solution and tubes were incubated at $56{ }^{\circ} \mathrm{C}$ for 15 min. Lysis was performed adding $200 \mu$ l of Lysis Buffer VL-LB3 to the previous solution and mixing thoroughly. The solution was incubated at $70{ }^{\circ} \mathrm{C}$ for $10 \mathrm{~min}$. Then, $210 \mu \mathrm{l}$ of ethanol (96-100\%) were added and mixed thoroughly. The final mixtures were loaded on VK-DNA binding columns and centrifuged at 11,000 $\times$ $\mathrm{g}$ for $1 \mathrm{~min}$. Pass-through liquid was discarded. Washing steps were performed with $500 \mu \mathrm{l}$ of Wash Buffer VK-WB1 and $600 \mu \mathrm{l}$ of Wash Buffer VK-WB2 with a $11,000 \times \mathrm{g} 1 \mathrm{~min}$ centrifuging step in between. After washes were done, $100 \mu \mathrm{l}$ of Elution Buffer were added to the column and the column left for $1 \mathrm{~min}$. DNA was recovered by centrifuging at $11,000 \times \mathrm{g}$ for $1 \mathrm{~min}$. Extracted DNA was stored at $-20{ }^{\circ} \mathrm{C}$ until PCRs were performed. Negative DNA extraction controls (for every 23 samples), no template and positive PCR controls (for every PCR) were included in all downstream PCR assays.

\section{Solid medium isolated colonies}

A loopful of cells from each colony growing on solid medium was placed in $100 \mu \mathrm{l}$ of sterile water. Vials were incubated at $95{ }^{\circ} \mathrm{C}$ for $10 \mathrm{~min}$ and centrifuged at $13,800 \times \mathrm{g}$ for $5 \mathrm{~min}$. The supernatant was used as template for further PCR assays.

\section{Positive MGIT liquid medium}

One millilitre of vortexed liquid culture from the MGIT tubes was collected and centrifuged at $13,800 \times \mathrm{g}$ for $5 \mathrm{~min}$, the supernatant was discarded and after a washing with $1 \mathrm{ml}$ of sterile distilled water, the pellet was suspended in $250 \mu \mathrm{l}$ of sterile water. Then $300 \mathrm{mg}$ of zirconium beads were added and homogenized at $30 \mathrm{~Hz}$ for $10 \mathrm{~min}$ on TissueLyser II (Qiagen). Following homogenization, samples were centrifuged at $7500 \times \mathrm{g}$ for $15 \mathrm{~min}$ and the supernatant was collected.

\section{Molecular detection \\ Detection of mycobacteria by Tetraplex real-time PCR (MycMavMtc)}

For initial screening purposes to test the presence of Mycobacterium sp., a fourplex real-time PCR described by Sevilla et al. [31] was performed. This PCR is able to detect the genus Mycobacterium and then distinguish between the M. tuberculosis complex and M. avium subspecies. The target genes were the internal transcribed spacer (ITS) between $16 \mathrm{~S}$ and 23SrRNA genes, insertion sequence IS1311 and the devR genr for Mycobacterium genus, $M$. avium subspecies and M. tuberculosis complex members respectively.

Reactions were carried out in a final volume of $25 \mu \mathrm{l}$ containing $5 \mu \mathrm{l}$ of template DNA, and 1X TaqMan Universal PCR MasterMix without AmpErase uracil-DNA glycosylase (Applied Biosystems), $0.3 \mu \mathrm{M}$ of each primer, $0.2 \mu \mathrm{M}$ of each probe. An internal amplification control (IAC) was included in the reaction to rule out false negative results due to inhibitors. ROX (6-carboxyl-Xrhodamine) dye was used as passive reference reporter. Amplification was carried out in a 7500 Real-Time PCR instrument (Applied Biosystems) and consisted of one denaturation and polymerase activation cycle of $10 \mathrm{~min}$ at $95^{\circ} \mathrm{C}$, and 45 cycles of denaturation at $95{ }^{\circ} \mathrm{C}$ for $15 \mathrm{~s}$ and annealing/extension at $60^{\circ} \mathrm{C}$ for $1 \mathrm{~min}$. Results were analyzed using the 7500 System SDS software v. 1.4 (Applied Biosystems). Threshold cycle $\left(C_{T}\right)$ and baseline were automatically determined by the software and verified by visual examination of the threshold line in amplification plots.

\section{M. avium subsp. paratuberculosis detection by IS900 \& ISMap02 real-time PCR}

To identify Map positive samples, a real time multiplex PCR described by Sevilla et al. [32] was performed. This PCR detects IS900 and ISMap02 DNA sequences of $M$. avium subsp. paratuberculosis.

Briefly, the reaction mixture contained $1 \times$ TaqMan Universal PCR Master Mix (Applied Biosystems), 300$400 \mathrm{nM}$ of each primer, $200 \mathrm{nM}$ of each probe, and $5 \mu \mathrm{l}$ of DNA extract in a final volume of $25 \mu \mathrm{l}$. An IAC is also included in the PCR reaction.

Amplification and real time measurement were performed in the same system and conditions as described in the previous PCR protocol.

\section{M. avium subsp. hominisuis and M. avium subsp. avium/M.} avium subsp. silvaticum detection by IS1245 \& IS901 PCR

In order to identify other M. avium subspecies, a previously published real time PCR was carried out, based on the detection of IS901 and IS1245 insertion sequences [33]. Maa/Mas organisms are positive for IS1245 and IS901, while Mah is only positive for IS1245. The PCR did not include DNA concentration standards for quantification purposes because the objective was just to detect and identify Mah and Maa/Mas.

The final reaction mixture contained the same PCR ingredients at the same concentration indicated above for Map PCR but primers and probes were those previously 
described by Slana et al. [33]. Amplification and real time measurement were performed in the same system and conditions as described in the previous PCR setting.

\section{$16 \mathrm{~S}$ rRNA gene sequencing of colonies on solid medium}

The identification of colonies grown on solid media that were not mycobacteria as assessed by previously described PCR methods was performed by $16 \mathrm{~S}$ rRNA gene sequencing. Amplification of target DNA was performed by PCR using bacterial universal primers pAF $\left(5^{\prime}\right.$ - AGA GTT TGA TCC TGG CTC AG-3') and 530R (5'-CCG CGG CKG CTG GCAC-3'). Amplification was carried out in a 2700 GeneAmp PCR Instrument (Applied Biosystems) and consisted of one denaturation and polymerase activation cycle of $4 \mathrm{~min}$ at $94{ }^{\circ} \mathrm{C}$, and 30 cycles of denaturation at $94{ }^{\circ} \mathrm{C}$ for $30 \mathrm{~s}$, annealing at $50{ }^{\circ} \mathrm{C}$ for $30 \mathrm{~s}$ and extension at $72{ }^{\circ} \mathrm{C}$ for $40 \mathrm{~s}$. The PCR product was cleaned with Illustra Exoprostar 1-Step (GE Healthcare Life Sciences) following manufacturer's instructions.

The sequencing reaction was carried out with BigDye ${ }^{\circ}$ Terminator v3.1 cycle sequencing kit (Applied Biosystems) and resolved with a $3130 \mathrm{ABI}$ (Applied Biosystems) capillary sequencer. Sequencing conditions consisted of 30 cycles of denaturation at $96{ }^{\circ} \mathrm{C}$ for $10 \mathrm{~s}$, annealing at $50{ }^{\circ} \mathrm{C}$ for $5 \mathrm{~s}$ and extension at $60^{\circ} \mathrm{C}$ for $4 \mathrm{~min}$. Sequence alignment was performed using BLAST (Basic Local Alignment Search Tool) and identification with $100 \%$ of coverage and $99-100 \%$ of identity was made.

\section{Gross pathology}

The whole digestive system of the rabbits was inspected for gross anatomical change. Samples from sacculus rotundus and vermiform appendix were collected for solid and/or liquid culture and histopathological analysis. Samples from sacculus rotundus, vermiform appendix and caecal contents were collected for detection of mycobacteria by PCR.

\section{Histopathology}

Histopathological analysis was performed on samples of sacculus rotundus and vermiform appendix and on other samples that presented macroscopic lesions. The tissues were fixed in $10 \%$ neutral buffered formalin for a minimum of $24 \mathrm{~h}$, trimmed, dehydrated through graded alcohols, embedded in paraffin wax and sectioned at $5 \mu \mathrm{m}$. These sections were mounted on glass slides stained with haematoxylin and eosin (HE) or by the Ziehl-Neelsen (ZN) method for acid fast bacteria (AFB) according to standard procedures. Slides were examined under the microscope for granuloma formation and AFB presence.

\section{Statistical analysis}

Association of mycobacteria detection and age was tested with the Chi square or Fisher exact probability
(FET) tests for the frequencies of PCR results according to age using the PROC FREQ of the SAS statistical package (SAS Institute Inc., Cary, NC, USA). For all analyses, a $\mathrm{p}$ value of $<0.05$ was considered to be statistically significant.

\section{Results \\ PCR evaluation}

MycMavMtc PCR results of the spiked rabbit mucosa are shown in Table 1. Inhibition was observed at all bacterial concentrations when samples were not diluted and only probe IS1311 was detected in the highest concentration. After dilution steps were performed, inhibitory effects were mitigated. In the medium concentration bacterial suspension a $1 / 2$ dilution was enough to detect M. avium sp. DNA by the IS1311 probe. However, in the low concentration inoculum after $1 / 2$ and $1 / 4$ dilutions the IS1311 probe was not positive and only the internal amplification control gave significant $C_{T}$ values.

\section{Slaughterhouse sample study Gross pathology and digestive system parameters}

Of the 66 necropsied animals, 6 (9\%) showed visible pathological lesions consistent with mycobacterial infection. They were characterized by the presence of focal thickenings of the intestinal wall in the sacculus rotundus and vermiform appendix together with the presence of pale-whitish spots consistent with lymphoid follicle hyperplasia. Jejunal and ileal wall thickening was observed in one and three animals respectively, affecting some areas of the intestine in these regions. Representative photographs of lesions observed in three different animals are shown in Fig. 2.

\section{Molecular detection}

Of the 66 analyzed rabbits, 11 were positive for $M$. avium in GALT (16.66 \%). Of these, six animals (54.54\%) were positive in vermiform appendix only, 2 (18.18 \%) in sacculus rotundus only, and $3(27.27 \%)$ in both tissue types. $\mathrm{C}_{T} \mathrm{~s}$ for IS1311 probe were $36.48+/-2.32$ for undiluted samples and $37.12+/-1.01$ for diluted samples. Attending to tissue type, $\mathrm{C}_{T} \mathrm{~s}$ were $36.94+/-0.83$ for vermiform appendix and $35.83+/-3.88$ for sacculus rotundus. Mycobacteria were not detected by PCR in caecal contents.

The 14 M. avium positive samples were further analyzed by IS 900 \& IsMap02 PCR for Map detection and IS1245 \& IS901 PCR for differentiation between Maa/ Mas and Mah. All these samples were negative for the first real-time PCR, meaning that Map was not detected in these rabbits. In contrast 13 of the $M$. avium positive samples were identified as Maa/Mas and 1 was identified as Mah according to the results obtained with IS1245 \& IS901 PCR (Table 2). 
Table 1 M. avium subsp hominissuis spiked rabbit mucosa $C_{T S}$ of MycMavMtc PCR

\begin{tabular}{|c|c|c|c|c|}
\hline \multirow[b]{3}{*}{ Dilution } & \multirow[b]{3}{*}{ DNA Probe } & \multicolumn{3}{|c|}{ Mah spiked rabbit mucosa } \\
\hline & & high & medium & low \\
\hline & & $7.66 \times 10^{6}(\mathrm{CFU} / \mathrm{g})$ & $7.66 \times 10^{4}(\mathrm{CFU} / \mathrm{g})$ & $7.66 \times 10^{2}(\mathrm{CFU} / \mathrm{g})$ \\
\hline \multirow[t]{3}{*}{$1 / 1$} & ITSdenak & UD & UD & UD \\
\hline & IS1311 & 31.77 & UD & UD \\
\hline & IAC & UD & UD & UD \\
\hline \multirow[t]{3}{*}{$1 / 2$} & ITSdenak & 43.56 & UD & UD \\
\hline & IS1311 & 28.5 & 36.66 & UD \\
\hline & IAC & 35.1 & 41.19 & 36.00 \\
\hline \multirow[t]{3}{*}{$1 / 4$} & ITSdenak & 39.7 & UD & UD \\
\hline & IS1311 & 28.85 & 34.50 & UD \\
\hline & IAC & 32.62 & 33.99 & 33.63 \\
\hline
\end{tabular}

Mah: M. avium subps. hominissuis, ITSdenak: detects Mycobacterium genus, IS1311: detects Mycobacterium avium, IAC: internal amplification control, UD: undetermined no threshold-crossing fluorescence, devR detecting Mtb complex members was UD for all assayed conditions

\section{Culture}

The culture of samples in BACTEC MGIT recorded contamination of $19.69 \%$ of sacculus rotundus and $7.5 \%$ of vermiform appendix samples. The remaining samples gave TTD readouts compatible with mycobacterial growth patterns on an average of 7.36 days for samples of sacculus rotundus and 6.95 days for samples of vermiform appendix but with a negative result in the MycMavMtc PCR. As a consequence, all MGIT cultures were finally recorded as contaminated.

No contamination on solid media was observed. Four samples cultured on Lowenstein-Jensen solid medium yielded colonies that were negative in the MycMavMTC. Sequencing of $16 \mathrm{~S}$ rRNA gene identified them as Thermoactinomycetaceae bacterium W8742 in three cases and Thermoactinomyces sanguinis in one case (Table 3).

\section{Histopathology}

Most significant lesions were found in the sacculus rotundus and vermiform appendix lymphoid tissue. In some cases, they were formed by well demarcated granulomas compatible with mycobacterial infection, composed of between 10-50 macrophages with occasional multinucleated Langhan's type giant cells, located in the interfollicular areas of the lymphoid tissue. In other animals, granulomatous lesions were categorized as unspecific and were formed by small granulomas, also seen in the interfollicular areas of lymphoid tissue, with less than 15 macrophages, harbouring variable amounts of a brown pigment in their cytoplasm. Microscopical examination of tissues revealed that wall thickening observed on ileum and jejunum corresponded to reactive lymphoid follicles in the ileal and jejunal Peyer's patches. Remaining samples were
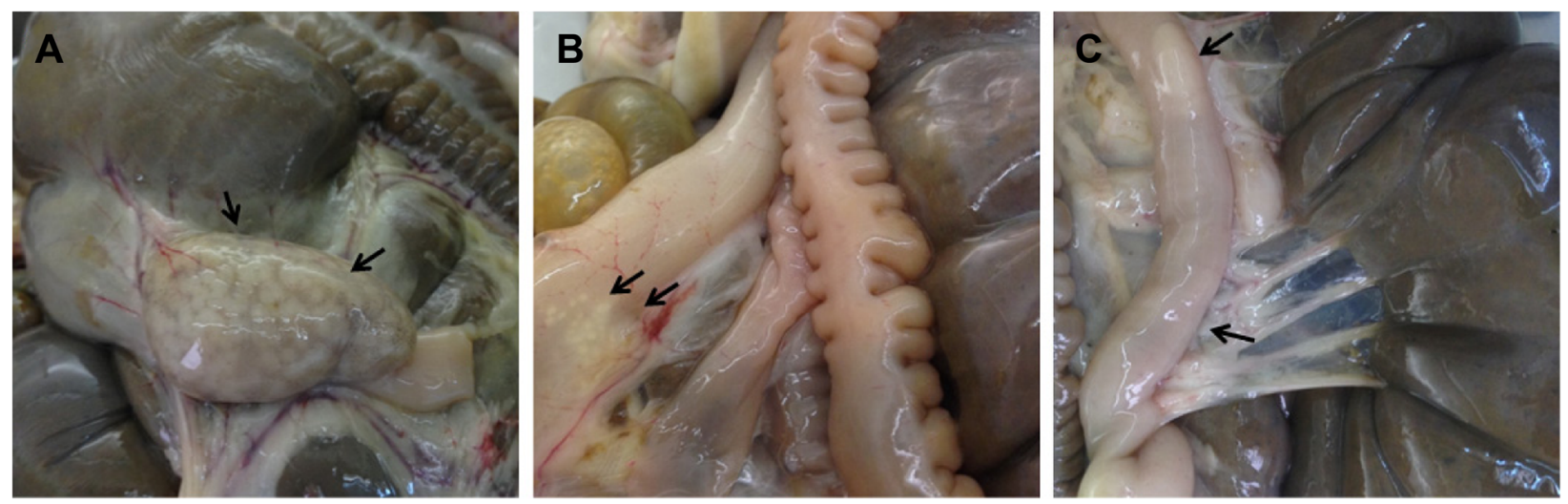

Fig. 2 Macroscopic lesions found in slaughtered rabbits. a sacculus rotundus with pale white spots and thickened wall (animal D2.B2), b vermiform appendix with white spots and thickened wall (animal E1.Y2), c ileum with thickened walls and a reactive Peyer's patch (animal C1.Y2) 
Table 2 Gross pathology and molecular detection of sacculus rotundus and vermiform appendix from analyzed slaughtered rabbits

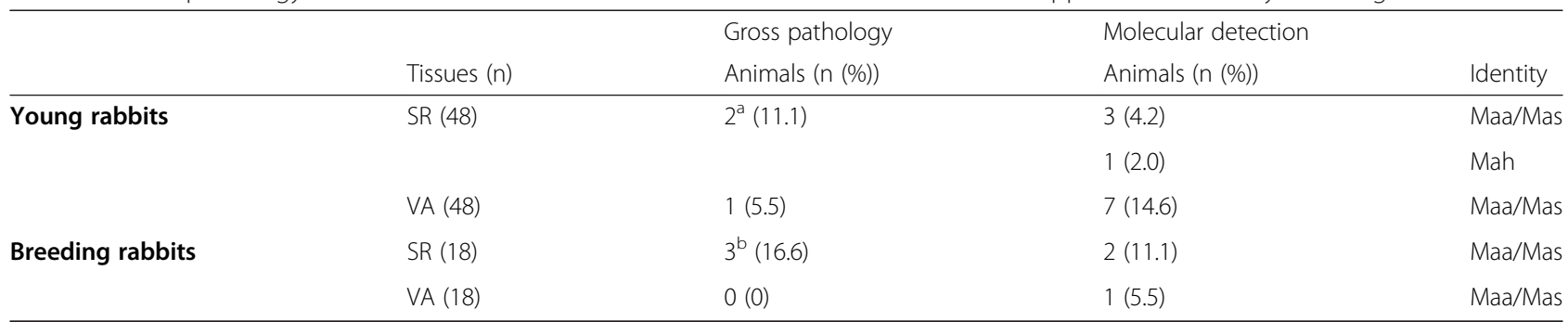

$\mathrm{n}$ : number of tissues or animals, \%: percentage of positive results, SR: sacculus rotundus, VA: vermiform appendix, Maa: M. avium subsp. avium, Mas: M. avium subsp silvaticum, Mah: M. avium subsp hominissuis a Lesions spread to the ileum in both animals, ${ }^{b}$ Lesions spread to the ileum in one animal

classified as reactive hyperplasic or absence of lesion when tissues presented a normal form. AFB were detected on two samples that were classified as absence of lesion and were also PCR positive. Complete results for all animals are shown in Table 3.

\section{Association analysis}

Analysis of age and gross pathology results showed that 6 out of $48(6.25 \%)$ of the young rabbits and 3 out of 18 (16.7\%) breeding rabbits showed some gross changes. However, these frequencies were not statistically significant $($ FET $p=0.333)$.
Microbiological results showed that 9 of 48 (18.7\%) young rabbits and 2 of 18 (11.1\%) breeding animals were $M$. avium subspecies positive in the PCR tests, but again, these frequencies were not statistically significant (FET $p=0.713$ ).

Worth mentioning is that $50 \%(2 / 4)$ of the samples that presented focal lesions were PCR positive.

The geographical origin of sampled rabbits is shown on Fig. 3a. All geographical areas except for $\mathrm{F}$ presented at least one positive farm as shown on Fig. 3b. 8 out of 21 farms were positive (38\%), when positive was considered as having at least one $M$. avium subspecies PCR positive animal. Noticeable, is geographical area $\mathrm{E}$ where

Table 3 Molecular analysis, gross pathology and histopathology results of animals with at least one positive result in any of the methods

\begin{tabular}{|c|c|c|c|c|c|c|}
\hline \multicolumn{3}{|c|}{ MycMavMtc PCR } & \multirow[t]{2}{*}{ Identity } & \multirow[t]{2}{*}{ 16s rRNA gene sequencing } & \multirow{2}{*}{$\begin{array}{l}\text { Gross } \\
\text { pathology }\end{array}$} & \multirow[t]{2}{*}{ Histopathology } \\
\hline Animal & $\mathrm{SR}$ & VA & & & & \\
\hline E1.Y1 & - & - & - & Thermoactinomyceteae $e^{a}$ & - & SR $(0) /$ VA (0) \\
\hline E1.Y2 & - & + & Maa/Mas & $\mathrm{Nl}$ & VA & SR (0)/ VA (0) \\
\hline B1.B1 & - & - & - & Thermoactinomyceteae $e^{b}$ & - & NA \\
\hline B1.B2 & - & - & - & $\mathrm{NI}$ & SR & SR (0)/ VA (0) \\
\hline E2.Y2 & - & - & - & $\mathrm{Nl}$ & $\mathrm{SR} / \mathrm{IL}^{\mathrm{C}} / \mathrm{JE}^{\mathrm{C}}$ & $\mathrm{SR}(3) / \mathrm{VA}(0) / \mathrm{IL}(1) / \mathrm{JE}(0)$ \\
\hline C1.Y2 & + & + & Maa/Mas & $\mathrm{NI}$ & $S R / I L^{c}$ & $\mathrm{SR}(0)^{\mathrm{d}} / \mathrm{VA}(1) / \mathrm{IL}(1)$ \\
\hline C2.Y1 & - & + & Maa/Mas & $\mathrm{NI}$ & - & SR (1)/ VA (3) \\
\hline C2.Y2 & - & + & Maa/Mas & $\mathrm{NI}$ & - & $S R(0) / V A(0)^{d}$ \\
\hline B2.Y2 & - & - & - & Thermoactinomyceteae ${ }^{a}$ & - & $\mathrm{SR}(0) / \mathrm{VA}(0)$ \\
\hline A1.Y2 & - & + & Maa/Mas & $\mathrm{NI}$ & - & NA \\
\hline E3.Y1 & - & + & Mah & $\mathrm{Nl}$ & - & NA \\
\hline E3.Y2 & - & + & Maa/Mas & $\mathrm{Nl}$ & - & NA \\
\hline B7.Y1 & - & - & - & Thermoactinomyces sanguinis ${ }^{\mathrm{b}}$ & - & NA \\
\hline B5.B1 & + & + & Maa/Mas & $\mathrm{Nl}$ & - & NA \\
\hline D2.Y2 & + & + & Maa/Mas & $\mathrm{Nl}$ & - & NA \\
\hline $\mathrm{D} 2 . \mathrm{B} 1$ & - & - & - & $\mathrm{NI}$ & $S R / L^{c}$ & $\mathrm{SR}(2) / \mathrm{VA}(0) / \mathrm{IL}(1)$ \\
\hline D2.B2 & + & - & Maa/Mas & $\mathrm{NI}$ & SR & $\mathrm{SR}(2) / \mathrm{VA}(0)$ \\
\hline D3.Y1 & + & - & Maa/Mas & $\mathrm{NI}$ & - & NA \\
\hline
\end{tabular}

SR: sacculus rotundus, VA: vermiform appendix, IL: ileum, JE: jejunum, NI: no isolation. ${ }^{a}$ Identified from a colony isolated from sacculus rotundus, ${ }^{b}$ Identified from a colony isolated from vermiform appendix. 'intestinal wall thickening, NA: Not analyzed. (0): Without lesions, (1): Reactive hyperplasia, (2) Unspecific granulomatous lesions (3): Granulomatous lesions, ${ }^{\mathrm{d}}$ : Ziehl Neelsen positive 
only 2 animals were sampled and one was positive for Maa and the other for Mah.

\section{Discussion}

There is not much information in the veterinary literature concerning microbiological findings from rabbits at slaughter. A few studies have assessed Listeria, Salmonella, and E.coli among others [34, 35]. It is not surprising then, that data from mycobacteria and more specifically $M$. avium subspecies is scarce and mainly limited to other animal species such as cattle [28] or pigs [26, 27]. Therefore, to the best of our knowledge, this is the first study reporting $M$. avium subspecies detection in slaughtered rabbits.
In rabbits, apart from mesenteric lymph nodes and Peyer's patches, the GALT which accounts for $50 \%$ of the lymphoid tissue includes two specific structures: the sacculus rotundus, and the vermiform appendix. Both tissue types present $M$ cells [36] which actively uptake and present particular antigens and microorganisms to the immune cells of the lymphoid follicle to induce an effective immune response [37]. Map has been reported to enter the domes of the Peyer's patches through $M$ cells [38] so orally ingested mycobacteria should end up in these sites and/or in caecal content and therefore we chose these specimens for our analysis.

Regarding PCR evaluation, the possibility of inhibition was the main concern. MycMavMtc PCR performed well at $10^{4}-10^{6} \mathrm{CFU} / \mathrm{g}$ of tissue. According to our results if

A
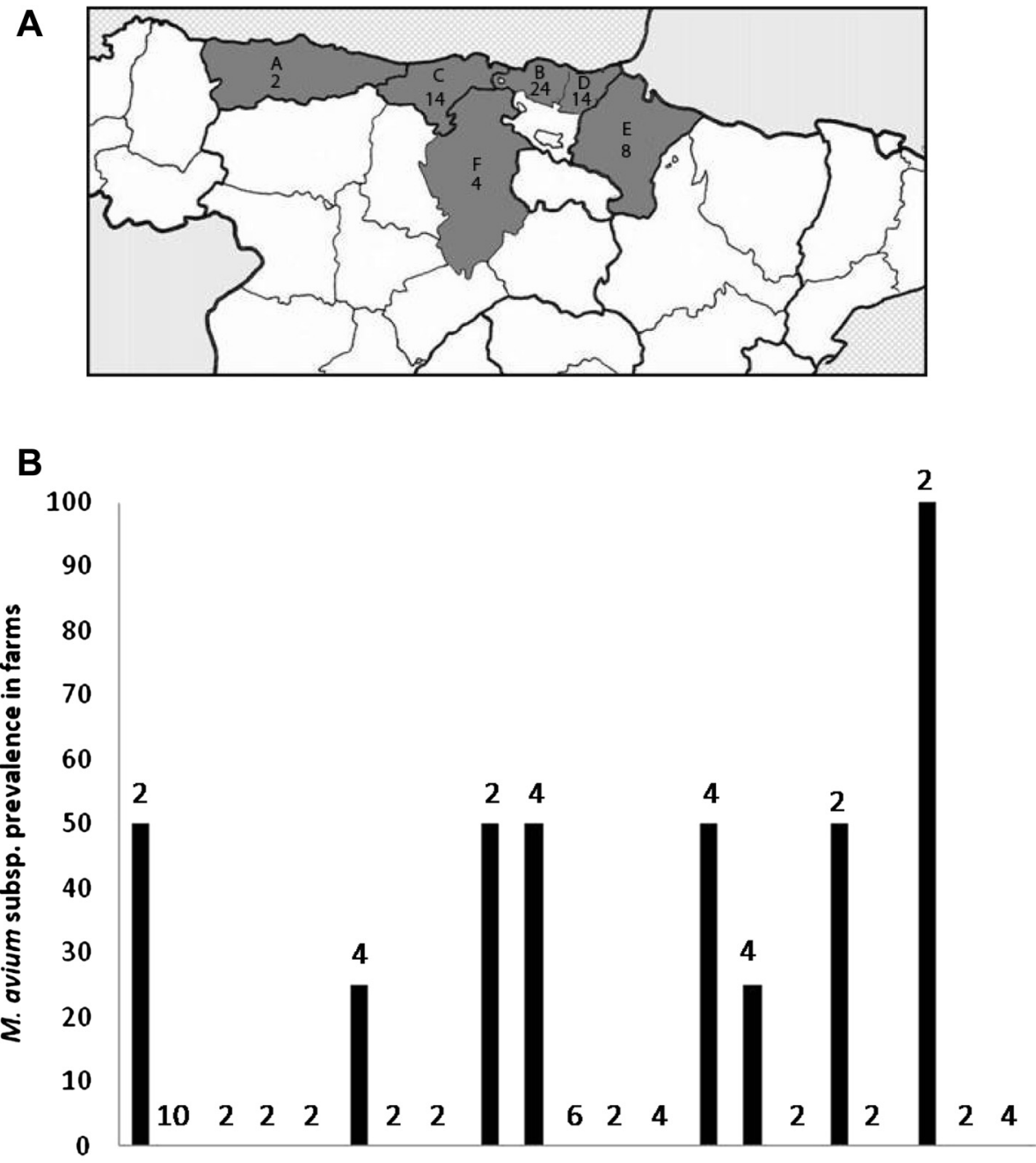

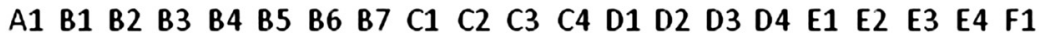

Fig. 3 a Geographical origin of sampled slaughtered rabbits. A: Asturias, B: Bizkaia, C: Cantabria, D: Gipuzkoa, E: Navarra, F: Burgos and number of analyzed animals per area. b M. avium subspecies positivity of each farm identified as letters (A-F) representing each geographical area and a number (1-7) identifying the farm. Black bars represent prevalence (\%), numbers on bars represent total number of analyzed animals from each farm 
we had $+/-10^{2} \mathrm{CFU} / \mathrm{g}$ of mycobacteria we would probably not detect them at least in our tissue type because we would necessarily have to perform dilution steps. The detection limit for this PCR for M. avium hominissuis in a mixture of bovine tissues has been reported as $1.59 \times 10^{2} \mathrm{CFU} / \mathrm{g}$ [32] which is in near agreement with our findings. We must add that the DNA extraction methods of both studies are not coincident and that the bovine tissue mixture may present a more favorable chemistry for the DNA extraction and PCR reaction compared to rabbit mucosa. In any case, for the slaughterhouse study we decided to dilute template DNA if inhibition took place, maybe missing positive samples in return.

In the slaughterhouse study, although gross pathology compatible with mycobacterial infection was seen, histological analysis of GALT did not reveal presence of granulomas in all gross pathology positive animals and AFB detected by ZN were only found in two cases. The presence of granulomas in GALT associated to Mah have been reported before in sheep [39]. The unspecific granulomas may not be due to infectious agents and they may be "garbage" granulomas or on the other hand they can be ancient granulomas that accumulate waxy pigments that have been attributed to mycobacteria in previous studies [40].

DNA of M. avium was present in $16.6 \%$ of the analyzed GALT samples. If we compare $\mathrm{C}_{T}$ values in sampled tissues with the PCR of artificially spiked tissues we can estimate that the bacterial load is probably below $10^{4} \mathrm{CFU} / \mathrm{g}$. In an experimental infection in rabbits with Map, isolation was variable, since some sacculus rotundus and vermiform appendix samples that had bacterial loads of $10^{2}-10^{6}$ genomic equivalents/g estimated by qPCR gave positive solid culture results, whereas the same tissue site samples from other animals with $10^{1}$ $10^{5}$ genomic equivalents/g gave negative culture results (unpublished observations). Of course, isolation variability can be affected by the irregular distribution of AFB in the analyzed tissues among other factors. As for, liquid cultures, they were eventually contaminated and other bacteria could have used up the nutrients necessary for mycobacterial growth. MycMavMtc PCR of MGIT cultures was negative meaning that mycobacterial load was possibly under $1,59 \times 10^{2} \mathrm{CFU} / \mathrm{g}$, since this was the reported detection limit for MGIT culture in a bovine tissue mixture using $2 \% \mathrm{NaOH}$ [31]. If more than $2 \% \mathrm{NaOH}$ were to be used as in the present study (6\% $\mathrm{NaOH}$ ), it would probably affect mycobacterial viability and interfere with isolation in both solid and liquid media. In solid media, only Thermoactinomyces, bacteria were isolated. Thermoactinomyces species have been implicated as causal agents of farmer's lung diseases [41] since the disease appears in farmers that are in direct contact with mouldy hay and cereal grains where these bacterial species are known to be abundant. Also they are found in soil, rivers and dairy products [42]. We are not sure about the meaning of this finding but it could be that these bacteria are present in the grains that the rabbits are fed or in the straw litter that maybe used for nesting before kindling. In any case, it is worth mentioning that these bacteria survive decontamination techniques used for mycobacterial culture and that no macro or microscopic signs of pathology in the digestive system were detected in the animals these bacteria were isolated from.

Association analysis revealed that neither gross pathology nor mycobacterial presence was affected by age. Maa has been detected before in rabbits that had been housed with infected pigeons [43] or with doves, ducks and chickens [44] suggesting in both cases that transmission had probably occurred from infected fowl to rabbits. In our case, although not specifically examined, given the standard production housing characteristics in the studied region, it is most probable that rabbits did not have direct contact with fowl. In any case, young rabbits do present Maa implicating an early contact in their life that might point to water or feeding.

The results from this study show that $M$. avium subspecies are widely spread and in contact with farmed rabbits since only 2-3 animals analyzed from each batch of 21 farms has shown $16.6 \%$ positivity among animals and $38 \%$ positivity among farms. Detection of mycobacterial DNA was achieved in $50 \%$ of the tissues with focal lesions, slightly higher than what has been reported for Map in cattle [40, 45]. At this point, we are not sure about the real significance of detecting $M$. avium subspecies in GALT tissue of slaughtered rabbits either from an animal pathological and epidemiological or Public Health perspective. Although detected granulomas suggest the generation of lesions, the focal nature of these granulomas could be compatible with a latent and controlled infection. Rabbit GALT does not enter the food chain, but if it occurred, properly cooked affected parts should not pose a risk to healthy or immunocompromised individuals. Scarcity of previous reports indicates that the problem probably does not compromise rabbit production to a big extent. Lack of other information on the infected animals such as clinical status or weight at slaughter impedes drawing conclusions. It is noteworthy to state that no Map was detected or isolated, therefore indicating that its presence in wild rabbits might be related to environmental factors that do not occur in more controlled farm conditions or that its prevalence is lower and a higher number of animals should be tested. 


\section{Conclusions}

This study should be considered as a preliminary survey that might draw attention to a hitherto undetected potential problem. Future studies should consider including other intestinal sites, associated lymph nodes and respiratory tissues as well.

The detection MAC bacteria other than Map indicates that a niche for this group of mycobacteria does exist in farmed rabbits.

\section{Abbreviations}

Map: Mycobacterium avium subsp. paratuberculosis; Maa: Mycobacterium avium subsp. avium; Mah: Mycobacterium avium subsp. hominissuis; MAC: Mycobacterium avium complex; AFB: Acid fast bacilli; GALT: Gut associated lymphoid tissue; HE: Haematoxylin and eosin; ZN: Ziehl-Neelsen; HEYM: Herrold's Egg Yolk Medium; PBS: Phosphate buffered saline; PBSGT: PBS $0.2 \%$ glycerol $0.05 \%$ Tween 80; MGIT: Mycobacteria Growth Indicator Tubes; TTD: Time to detection; FET: Fisher exact probability; CFU: Colony forming unit; PCR: Polymerase chain reaction; $C_{T}$ : Threshold cycle; IAC: Internal amplification control; ROX: 6-carboxyl-X-rhodamine; UD: Undetermined; NI: No isolation; NA: Not analyzed; SR: Sacculus rotundus; VA: Vermiform appendix; IL: Ileum; JE: Jejunum.

\section{Competing interests}

The authors declare that they have no competing interests.

\section{Authors' contribution}

RA collected the samples, participated in all the microbiological and pathological studies and collaborated in the interpretation of the data and writing of the paper, IS participated in the analysis of the data, interpretation of the results and writing of the paper, EM contributed to the sample collection and microbiological studies, VP collaborated in the histopathological interpretation and paper drafting, JG collaborated in the interpretation of the results and the paper drafting, RJ conceived and designed the experiment, performed data analysis and drafting of the paper, NE conceived and designed the experiment, participated in sample collection, pathological studies, interpretation of the results and performed data analysis and writing of the paper. All the authors read and approved the final manuscript.

\section{Authors' information}

Rakel Arrazuria, DVMD; Iker A Sevilla, Bsc, PhD; Elena Molina, BSc; Valentín Pérez, DVMD, PhD, Joseba M Garrido, DVMD, PhD; Ramón A Juste, DVMD, PhD; Natalia Elguezabal, BSc, PhD.

\section{Acknowledgements}

The authors thank the official veterinarian, Susana Rodríguez and all the employees at the rabbit slaughterhouse for their collaboration in collecting the samples and also Dr. Patricia Vazquez for technical assistance with the histopathological analysis.

\section{Funding}

This study was supported by grants (AGL2012-39818-CO2-02) and (INIA, RTA2010-00022) from the Spanish Ministry of Economy and Competitiveness (MINECO) and the Spanish National Institute for Agricultural and Food Research and Technology, respectively. Rakel Arrazuria held a pre doctoral fellowship (BFI-2012-237) from the Basque Government. The funders had no role in study design, data collection and analysis, decision to publish, or preparation of the manuscript.

\section{Author details}

${ }^{1}$ Animal Health Department, NEIKER-Instituto Vasco de Investigación y Desarrollo Agrario, Berreaga, 1, 48160 Derio, Bizkaia, Spain. ²Departamento de Sanidad Animal, Facultad de Veterinaria, Universidad de León, León, Spain.

Received: 18 February 2015 Accepted: 20 May 2015

Published online: 11 June 2015

\section{References}

1. Angus KW. Intestinal lesions resembling paratuberculosis in a wild rabbit (Oryctolagus cuniculus). J Comp Pathol. 1990;103:101-5.

2. Beard PM, Rhind SM, Buxton D, Daniels MJ, Henderson D, Pirie A, et al. Natural paratuberculosis infection in rabbits in Scotland. J Comp Pathol. 2001;124:290-9.

3. Fuentes $\mathrm{O}$, Cebrian J. El conejo de monte ¿Reservorio de la paratuberculosis ovina y caprina? In: Abstract book. 1988. I Symposium de Patología Ovina y Caprina. Zaragoza, Spain.

4. Maio E, Carta T, Balseiro A, Sevilla IA, Romano A, Ortiz JA, et al. Paratuberculosis in European wild rabbits from the Iberian Peninsula. Res Vet Sci. 2011;91:212-8.

5. Harrenstien LA, Finnegan MV, Woodford NL, Mansfield KG, Waters WR, Bannantine JP, et al. Mycobacterium avium in pygmy rabbits (Brachylagus idahoensis): 28 cases. J Zoo Wildl Med. 2006;37:498-512

6. Mokresh AH, Czuprynski CJ, Butler DG. A rabbit model for study of Mycobacterium paratuberculosis infection. Infect Immun. 1989;57:3798-807.

7. Vaughan JA, Lenghaus C, Stewart DJ, Tizard ML, Michalski WP. Development of a Johne's disease infection model in laboratory rabbits following oral administration of Mycobacterium avium subspecies paratuberculosis. Vet Microbiol. 2005;105:207-13

8. Turenne CY, Wallace Jr R, Behr MA. Mycobacterium avium in the postgenomic era. Clin Microbiol Rev. 2007;20:205-29.

9. Biet F, Boschiroli ML, Thorel MF, Guilloteau LA. Zoonotic aspects of Mycobacterium bovis and Mycobacterium avium-intracellulare complex (MAC). Vet Res. 2005:36:411-36.

10. Pavlik I, Svastova P, Bartl J, Dvorska L, Rychlik I. Relationship between IS901 in the Mycobacterium avium complex strains isolated from birds, animals, humans, and the environment and virulence for poultry. Clin Diagn Lab Immunol. 2000;7:212-7.

11. Thorel MF, Huchzermeyer HF, Michel AL. Mycobacterium avium and Mycobacterium intracellulare infection in mammals. Rev Sci Tech. 2001;20:204-18.

12. Mijs W, de Haas P, Rossau R, Van der Laan T, Rigouts L, Portaels F, et al. Molecular evidence to support a proposal to reserve the designation Mycobacterium avium subsp. avium for bird-type isolates and M. avium subsp. hominissuis for the human/porcine type of M. avium. Int J Syst Evol Microbiol. 2002:52:1505-18.

13. Alvarez J, Castellanos E, Romero B, Aranaz A, Bezos J, Rodriguez S, et al. Epidemiological investigation of a Mycobacterium avium subsp. hominissuis outbreak in swine. Epidemiol Infect. 2011;139:143-8.

14. Lahiri A, Kneisel J, Kloster I, Kamal E, Lewin A. Abundance of Mycobacterium avium ssp. hominissuis in soil and dust in Germany - implications for the infection route. Lett Appl Microbiol. 2014;59:65-70

15. Behr MA, Kapur V. The evidence for Mycobacterium paratuberculosis in Crohn's disease. Curr Opin Gastroenterol. 2008:24:17-21.

16. Feller M, Huwiler K, Stephan R, Altpeter E, Shang A, Furrer $H$, et al. Mycobacterium avium subspecies paratuberculosis and Crohn's disease: a systematic review and meta-analysis. Lancet Infect Dis. 2007;7:607-13.

17. Juste RA, Elguezabal N, Garrido JM, Pavon A, Geijo MV, Sevilla I, et al. On the prevalence of $M$. avium subspecies paratuberculosis DNA in the blood of healthy individuals and patients with inflammatory bowel disease. PLoS ONE. 2008:3:e2537.

18. Masala S, Paccagnini D, Cossu D, Brezar V, Pacifico A, Ahmed N, et al. Antibodies recognizing Mycobacterium avium paratuberculosis epitopes cross-react with the beta-cell antigen ZnT8 in Sardinian type 1 diabetic patients. PLoS ONE. 2011;6, e26931.

19. Vazquez P, Garrido JM, Molina E, Geijo MV, Gómez N, Pérez V, et al. Latent infections are the most frequent form of paratuberculosis in slaughtered Friesian cattle. Span J Agric Res. 2014;12:1049-60.

20. Soltys MA, Wise DR. Atypical mycobacterium in tuberculosis-like lesions in wood pigeons. J Pathol Bacteriol. 1967;93:351-2

21. Jorgensen JB, Clausen B. Mycobacteriosis in a roe-deer caused by woodpigeon mycobacteria. Nord Vet Med. 1976;28:539-46.

22. Chiers K, Deschaght P, De BT, Dabrowski S, Kotlowski R, De CD, et al. Isolation and identification of Mycobacterium avium subspecies silvaticum from a horse. Comp Immunol Microbiol Infect Dis. 2012;35:303-7.

23. Thorel MF, Blom-Potar MC, Rastogi N. Characterization of Mycobacterium paratuberculosis and "wood-pigeon" mycobacteria by isoenzyme profile and selective staining of immunoprecipitates. Res Microbiol. 1990;141:551-61.

24. Klanicova B, Slana I, Vondruskova H, Kaevska M, Pavlik I. Real-time quantitative PCR detection of Mycobacterium avium subspecies in meat products. J Food Prot. 2011;74:636-40. 
25. Agdestein A, Olsen I, Jorgensen A, Djonne B, Johansen TB. Novel insights into transmission routes of Mycobacterium avium in pigs and possible implications for human health. Vet Res. 2014;45:46.

26. Muwonge A, Johansen TB, Vigdis E, Godfroid J, Olea-Popelka F, Biffa D, et al. Mycobacterium bovis infections in slaughter pigs in Mubende district. Uganda: a public health concern. BMC Vet Res. 2012;8:168.

27. van Ingen J, Wisselink HJ, van Solt-Smits CB, Boeree MJ, van Soolingen D. Isolation of mycobacteria other than Mycobacterium avium from porcine lymph nodes. Vet Microbiol. 2010;144:250-3.

28. Alonso-Hearn M, Molina E, Geijo M, Vazquez P, Sevilla I, Garrido JM, et al. Isolation of Mycobacterium avium subsp. paratuberculosis from muscle tissue of naturally infected cattle. Foodborne Pathog Dis. 2009;6:513-8.

29. Gonzalez P, Caravac FP. Producción de conejos de aptitud cárnica. In: Universidad de Sevilla, editor. Sistemas ganaderos en el siglo XXI. Volume 30. 2007. p. 443-61.

30. von Reyn CF, Waddell RD, Eaton T, Arbeit RD, Maslow JN, Barber TW, et al. Isolation of Mycobacterium avium complex from water in the United States, Finland, Zaire, and Kenya. J Clin Microbiol. 1993;31:3227-30.

31. Sevilla IA, Molina E, Elguezabal N, Pérez V, Garrido JM, Juste RA. Detection of mycobacteria, Mycobacterium avium subspecies and Mycobacterium tuberculosis complex by a novel tetraplex real-time PCR. J Clin Microbiol. 2015:53:930-40.

32. Sevilla IA, Garrido JM, Molina E, Geijo MV, Elguezabal N, Vazquez P, et al. Development and Evaluation of a Novel Multicopy-Element-Targeting Triplex PCR for Detection of Mycobacterium avium subsp. paratuberculosis in Feces. Appl Environ Microbiol. 2014;80:3757-68.

33. Slana I, Kaevska M, Kralik P, Horvathova A, Pavlik I. Distribution of Mycobacterium avium subsp. avium and M. a. hominissuis in artificially infected pigs studied by culture and IS901 and IS1245 quantitative real time PCR. Vet Microbiol. 2010;144:437-43.

34. Kohler R, Krause G, Beutin L, Stephan R, Zweifel C. Shedding of food-borne pathogens and microbiological carcass contamination in rabbits at slaughter. Vet Microbiol. 2008;132:149-57.

35. Rodriguez-Calleja JM, Garcia-Lopez I, Garcia-Lopez ML, Santos JA, Otero A. Rabbit meat as a source of bacterial foodborne pathogens. J Food Prot. 2006;69:1106-12

36. Beyaz F, Ergun E, Bayraktaroglu AG, Ergun L. The identification of intestinal $M$ cells in the sacculus rotundus and appendix of the Angora rabbit. Vet Res Commun. 2010;34:255-65.

37. Kucharzik T, Lugering N, Rautenberg K, Lugering A, Schmidt MA, Stoll R, et al. Role of M cells in intestinal barrier function. Ann N Y Acad Sci. 2000:915:171-83.

38. Momotani E, Whipple DL, Thiermann AB, Cheville NF. Role of M cells and macrophages in the entrance of Mycobacterium paratuberculosis into domes of ileal Peyer's patches in calves. Vet Pathol. 1988;25:131-7.

39. Benavides J, Garcia-Pariente C, Garrido JM, Sevilla IA, Garcia-Marin JF, Perez $\checkmark$, et al. Coexistence of granulomatous enteric inflammation and neoplasia in an adult sheep. Vet Pathol. 2013:50:1158-62.

40. Gonzalez J, Geijo MV, Garcia-Pariente C, Verna A, Corpa JM, Reyes LE, et al. Histopathological classification of lesions associated with natural paratuberculosis infection in cattle. J Comp Pathol. 2005;133:184-96.

41. Pepys J, Jenkins PA, Festenstein GN, Gregory PH, Lacey ME, Skinner FA Farmer's Lung. Thermophilic actinomycetes as a source of "Farmer's lung hay" antigen. Lancet. 1963;2:607-11

42. Lacey J\&CT. Genus Thermoactinomyces Tsiklinsky 1899, 501AL. In: S.T.Williams MES\&JGH, editor. Bergey's Manual of Systematic Bacteriology. Baltimore: Williams \& Wilkins; 1989. p. 2574-85.

43. Kriz P, Slana I, Kralik P, Babak V, Skoric M, Fictum P, et al. Outbreak of Mycobacterium avium subsp. avium infection in one flock of domestic pigeons. Avian Dis. 2011;55:503-8.

44. Lehmbecker A, Pfeifer F, Moser I, Wohlsein P. Spontaneous enzootic avian tuberculosis in domestic rabbits (Oryctolagus cuniculi f dom). KLEINTIERPRAXIS. 2010;55:21.

45. Vazquez P, Garrido JM, Juste RA. Specific antibody and interferon-gamma responses associated with immunopathological forms of bovine paratuberculosis in slaughtered Friesian cattle. PLoS ONE. 2013;8, e64568.

\section{Submit your next manuscript to BioMed Central and take full advantage of:}

- Convenient online submission

- Thorough peer review

- No space constraints or color figure charges

- Immediate publication on acceptance

- Inclusion in PubMed, CAS, Scopus and Google Scholar

- Research which is freely available for redistribution

Submit your manuscript at www.biomedcentral.com/submit 